\title{
Copper homeostasis in Enterococcus hirae
}

\author{
Marc Solioz *, Jivko V. Stoyanov \\ Department of Clinical Pharmacology, University of Berne, Murtenstrasse 35, 3010 Bern, Switzerland
}

Received 3 November 2002; received in revised form 29 January 2003; accepted 31 January 2003

First published online 6 May 2003

\begin{abstract}
Copper is an essential component of life because of its convenient redox potential of 200-800 $\mathrm{mV}$ when bound to protein. Extensive insight into copper homeostasis has only emerged in the last decade and Enterococcus hirae has served as a paradigm for many aspects of the process. The cop operon of E. hirae regulates copper uptake, availability, and export. It consists of four genes that encode a repressor, CopY, a copper chaperone, CopZ, and two CPx-type copper ATPases, CopA and CopB. Most of these components have been conserved across the three evolutionary kingdoms. The four Cop proteins have been studied in vivo as well as in vitro and their function is understood in some detail.
\end{abstract}

(C) 2003 Federation of European Microbiological Societies. Published by Elsevier Science B.V. All rights reserved.

Keywords: Copper; Silver; Enterococcus; Resistance; ATPase; Metallochaperone

\section{Contents}

1. Introduction $\ldots \ldots \ldots \ldots \ldots \ldots \ldots \ldots \ldots \ldots \ldots \ldots \ldots \ldots \ldots \ldots$

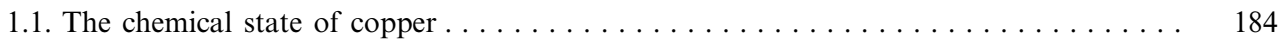

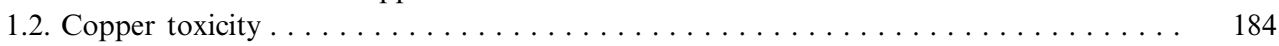

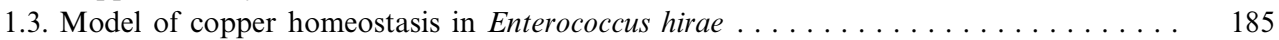

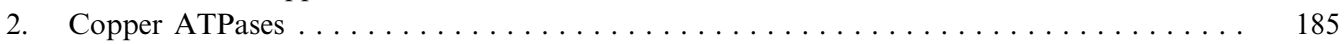

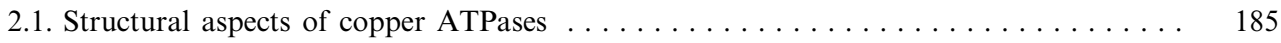

2.2. Evolutionary aspects of copper ATPases $\ldots \ldots \ldots \ldots \ldots \ldots \ldots \ldots \ldots \ldots \ldots$

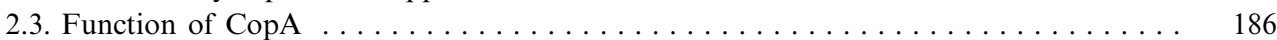

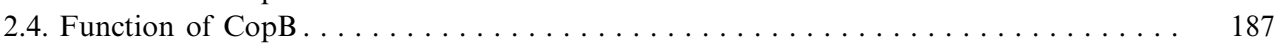

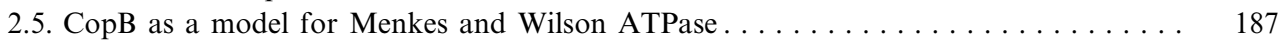

3. Regulation of the cop operon by the CopY repressor and the CopZ chaperone . . . . . 188

3.1. In vivo regulation of the $c o p$ operon $\ldots \ldots \ldots \ldots \ldots \ldots \ldots \ldots \ldots$

3.2. Structure of the CopY repressor $\ldots \ldots \ldots \ldots \ldots \ldots \ldots \ldots \ldots \ldots$

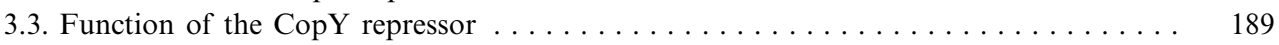

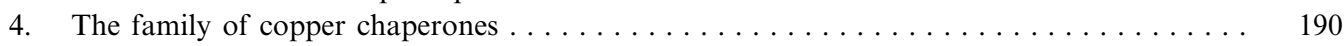

4.1. Structure of $\mathrm{CopZ} \ldots \ldots \ldots \ldots \ldots \ldots \ldots \ldots \ldots \ldots \ldots$

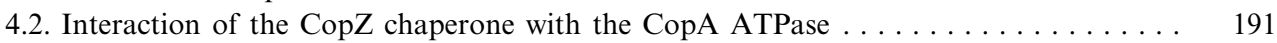

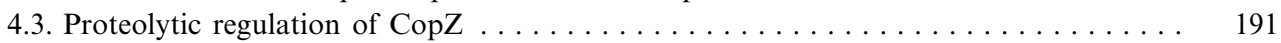

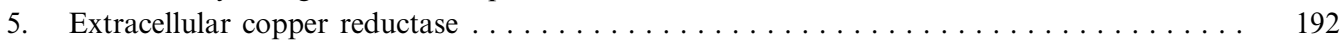

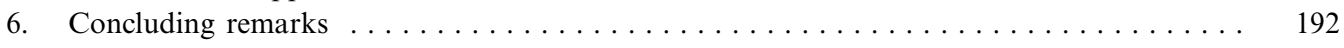

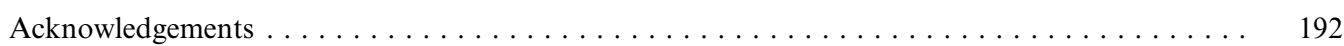

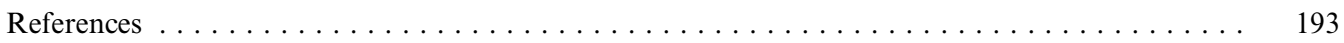

* Corresponding author. Tel.: +41 (31) 632 3268; Fax: +41 (31) 632 4997. E-mail address: marc.solioz@ikp.unibe.ch (M. Solioz). 


\section{Introduction}

Copper has been known since prehistoric times. It was obtained in the Middle East by charcoal reduction of its ores by about 3500 years before Christ. Approximately 500 years later, the harder bronze, generated by the addition of tin, was discovered; this established the Bronze Age. Copper has continued to be one of mankind's most important metals to this day. Copper is widely distributed in nature and has a relative abundance in the Earth's crust of $68 \mathrm{ppm}$. Copper is found mainly as the sulfide, oxide, or carbonate, its major ores being copper pyrite (chalcopyrite, $\mathrm{CuFeS}_{2}$ ), copper glance (chalcocite, $\mathrm{Cu}_{2} \mathrm{~S}$ ), cuprite $\left(\mathrm{Cu}_{2} \mathrm{O}\right)$, and malachite $\left(\mathrm{Cu}_{2} \mathrm{CO}_{3}(\mathrm{OH})_{2}\right)$. Weathered minerals give rise to soluble cupric and cuprous salts, such as carbonates and chlorides [1].

Copper is an essential micronutrient both for eukaryotes and prokaryotes. The biological functions of copper are closely related to its properties as a transition metal. Copper has partially filled $d$ orbitals and has more than one stable valence state, $\mathrm{Cu}(\mathrm{I})$ being a $\left(d^{10}\right)$ cation and $\mathrm{Cu}(\mathrm{II})$ being a $\left(d^{9}\right)$ cation. As the strongest Lewis acid in Group IB, copper has the ability to mediate electron transport, accepting and donating electrons used by metallo-enzymes like cytochrome $c$ oxidase, lysyl oxidase, or superoxide dismutase [2]. Copper can also be a prosthetic group of microbial enzymes involved in the reduction of nitrite and nitrous oxides. Another class of copper proteins, exemplified by plastocyanins and azurins, act as electron carriers. Second only to iron, copper is the biologically most used transition metal. However, its homeostasis has to be tightly regulated, because it is also toxic. Studies of microbial model systems and the investigation of inherited diseases in copper metabolism led to important insight into the mechanism of copper toxicity and the way cells deal with it.

\subsection{The chemical state of copper}

The two oxidation states of copper, $\mathrm{Cu}^{+}(\operatorname{copper}(\mathrm{I}))$ and $\mathrm{Cu}^{2+}$ (copper(II)), are what make copper a valuable cellular constituent. It participates in biological redox reactions by undergoing cycling between the two oxidation states, thereby taking up and releasing electrons. Such redox-active copper ions are deeply buried in specialized cuproenzymes. While free copper(II) ions are stable in neutral, aqueous solutions exposed to the atmosphere, copper(I) ions can only be maintained in solution at very acidic $\mathrm{pH}$ or in complexed form. Copper in both oxidation states avidly binds to biomolecules, preferentially involving thiols. Highly efficient chelators of copper(I) in vitro are $o$-phenanthroline, bathophenanthroline sulfonate or 8-hydroxyquinoline (reported formation constants for copper-phenanthroline complexes are around 21 , irrespective of the ligands on the phenanthroline dipyrimidine ring system [3]). Stable copper(I) complexes are also formed by acetonitrile [4], $\mathrm{CN}^{-}$, or even Tris-buffer [5]. More recently, tetrathiomolybdate has been employed as a very potent copper chelator in experimental systems [6]. This compound has also undergone phase II clinical trials for the removal of copper in people suffering from Wilson disease [7], a condition where copper accumulates in the liver due to a genetic fault in the Wilson copper ATPase, ATP7B [8]. Phenanthrolines complex Cu(I) (and $\mathrm{Fe}(\mathrm{II})$ ) so strongly that they effectively raise the redox potential to a point at which any reducing equivalent can support the reduction of the higher valency metal ion. This reaction can be counteracted by high concentrations $(20 \mathrm{mM})$ of citrate or lactate, which preferentially bind the oxidized form of copper.

It has been shown that copper ATPases transport copper(I) and that copper chaperones shuttle copper(I) (see below). High backgrounds of non-specific copper binding, strictly anaerobic working conditions, and the use of copper chelators and reductants have to be dealt with when working with copper(I). The use of reducing agents, copper chelators, and the binding of copper(I) to biological material, on the other hand, allow only estimates of the available copper concentration in a given system. These are the major hurdles for in vitro experiments with copper homeostatic components.

\subsection{Copper toxicity}

The mode of toxicity of copper is not fully understood. Copper toxicity could occur via the production of hydroxyl radicals $\left(\mathrm{OH}^{\circ}\right)$ in a Fenton-type reaction.

$$
\mathrm{Cu}^{+}+\mathrm{H}_{2} \mathrm{O}_{2}=\mathrm{Cu}^{2+}+\mathrm{OH}^{-}+\mathrm{OH}^{\bullet}
$$

The highly reactive hydroxyl radicals could damage phospholipids and enzymes [9]. Hydroxyl radicals could also attack DNA bases, preferentially guanine residues, and break phosphodiester bonds in single-stranded DNA by modifying the deoxyribose sugars. However, the estimated steady-state concentrations of oxygen and hydrogen peroxide under physiological conditions are $10^{-5}$ and $10^{-9}$ $\mathbf{M}$, respectively [10]. This makes the generation of hydroxyl radicals by reaction (1) unfavorable, except in hypoxia. Under normal conditions, redox cycling by reactions (2) and (3) should be more favorable.

$$
\begin{aligned}
& 2 \mathrm{Cu}^{2+}+2 \mathrm{GSH}=2 \mathrm{Cu}^{+}+\mathrm{GSSG}+2 \mathrm{H}^{+} \\
& 2 \mathrm{Cu}^{+}+2 \mathrm{H}^{+}+\mathrm{O}_{2}=2 \mathrm{Cu}^{2+}+\mathrm{H}_{2} \mathrm{O}_{2}
\end{aligned}
$$

These combined reactions cause redox cycling of copper at the expense of glutathione $(\mathrm{GSH})$ and $\mathrm{O}_{2}$ to produce GSSG, the reduced form of GSH [11]. Other thiols could be depleted by the same reaction. Extensive thiol depletion would of course impair cell function (most Gram-positive organisms apparently do not contain GSH and its deple- 


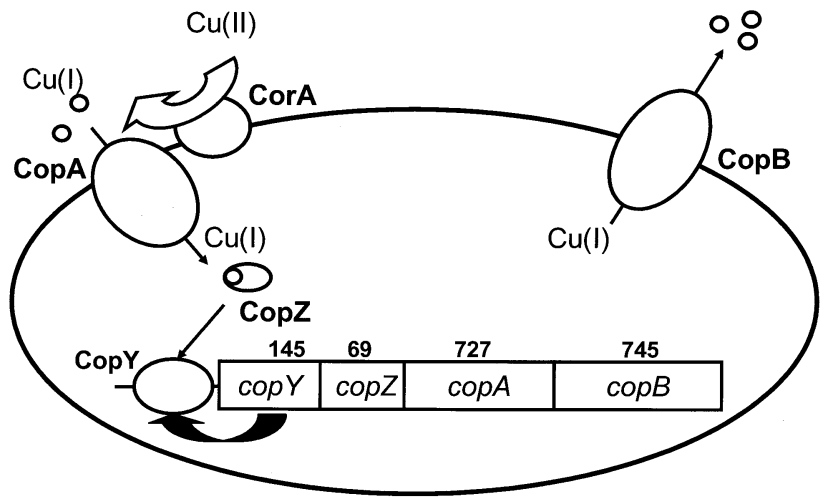

Fig. 1. Model of the cop operon and copper homeostasis in E. hirae. The extracellular reductase CorA supplies copper(I) for uptake by CopA. Inside the cell, copper is routed from the CopA ATPase to the CopY repressor by the CopZ copper chaperone. The copper form of CopY is released from the promoter, thereby allowing expression of the four cop genes. In the case of excess copper, CopZ may deliver copper to the CopB copper export ATPase. The numbers indicate the number of amino acids of the respective proteins.

tion would thus not be a toxicological mechanism in such organisms [12]; however, streptococci and enterococci appear to be exceptions which do contain GSH [13]). GSH has also been shown to be a normal copper ligand, participating in copper transport and/or detoxification [14]. GSH depletion would of course adversely affect such functions.

Kocha et al. have reported that mannitol scavenges hydroxyl radicals and in vitro effectively protects albumin from oxidative damage in a $\mathrm{Fe}^{2+} / \mathrm{EDTA} / \mathrm{H}_{2} \mathrm{O}_{2}$ system, but not in a $\mathrm{Cu}^{2+} / \mathrm{H}_{2} \mathrm{O}_{2}$ system [15]. They propose that copper, but not iron, first binds to the proteins and then generates the reactive hydroxyl radical at the copper binding site. Whatever the primary toxic effects of copper may be, they are utilized in agriculture for the control of bacterial and fungal diseases on a variety of crops, such as potatoes or grapes [16].

\subsection{Model of copper homeostasis in Enterococcus hirae}

For the safe management of copper, prokaryotic and eukaryotic cells have developed various mechanisms. Copper homeostasis in E. hirae has been extensively studied and reviewed [17-21] and is the best understood prokaryotic copper homeostasis system. It consists of four genes arranged in the cop operon. The gene products of cop $A$ and $\operatorname{cop} B$ are copper transporting ATPases, cop $Y$ encodes a copper-responsive repressor, and cop $Z$ encodes a chaperone which can catalyze intracellular copper routing (Fig. $1)$. The cop operon allows growth of $E$. hirae in a wide range of copper concentrations, from copper-limiting conditions to $8 \mathrm{mM}$ copper. According to the model, CopA takes up copper when copper is limiting, $\mathrm{CopB}$ extrudes copper when it reaches toxic concentrations, CopY regulates the expression, and CopZ transfers copper to CopY. In the following section, structural and functional aspects of these components and their interaction will be discussed in detail.

\section{Copper ATPases}

The E. hirae copper ATPases were discovered fortuitously. While trying to clone a potassium ATPase using an antibody to screen an expression library, a clone encoding the two copper ATPases, CopA and CopB, was isolated. $\operatorname{Cop} A$ and $\operatorname{cop} B$ were the first genes encoding copper ATPases to be described [22]. In 1993, a homologous human copper ATPase defective in Menkes disease, a severe X-linked condition of copper deficiency [8], was cloned simultaneously by three groups [23-25]. The discovery of this ATPase, ATP7A or MNK, was shortly followed by the cloning of a second human copper ATPase, ATP7B or WND [26,27]. Mutations in ATP7B lead to Wilson disease, a failure to secrete excess copper from the liver, resulting in severe liver damage [8]. These discoveries were followed by the description of numerous similar copper ATPases from yeast, plants, insects and bacteria [28,29]. Together with ATPases pumping a range of other heavy metal ions, namely $\mathrm{Cu}^{+}, \mathrm{Ag}^{+}, \mathrm{Co}^{2+}, \mathrm{Zn}^{2+}, \mathrm{Cd}^{2+}, \mathrm{Hg}^{2+}$, and $\mathrm{Pb}^{2+}$, they form the large new class of heavy metal ion ATPases [30,31].

\subsection{Structural aspects of copper ATPases}

The heavy metal ATPases are a sub-class of the P-type ATPases. These get their name from the fact that the aspartic acid of the universally conserved sequence DKTGT in the 'phosphorylation domain' forms a phosphorylated intermediate in the course of the reaction cycle [32]. Other motifs common to P-type ATPases are the

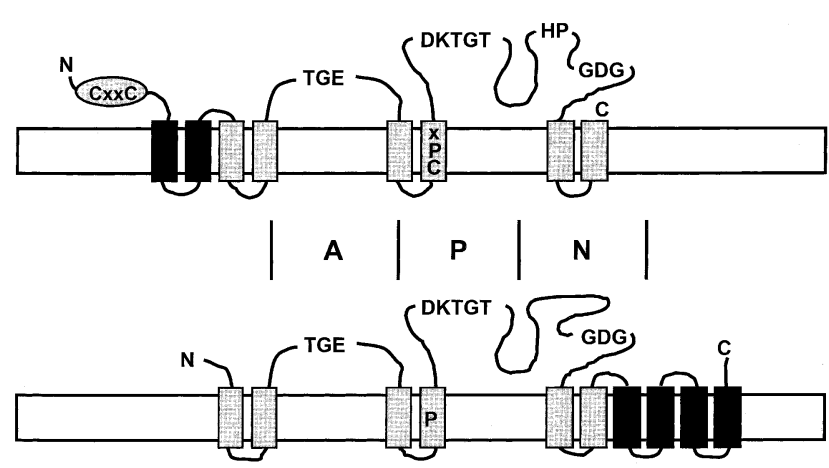

Fig. 2. Schematic comparison of heavy metal and non-heavy metal ATPases. Heavy metal ATPases (top) exhibit features not found in any of the non-heavy metal ATPases (bottom): (i) one to six heavy metal binding sites with $\mathrm{CxxC}$ motifs or a histidine-rich region at the N-terminus, (ii) a conserved intramembranous $\mathrm{CPC}$, SPC, or CPH motif in membrane helix 6, (iii) a conserved HP motif $34-43$ amino acids C-terminal to the CPx motif, (iv) two additional transmembrane helices at the N-terminal end of the protein, and (v) a lack of four membrane spans at the $\mathrm{C}$-terminal end. A, actuator domain; $\mathrm{P}$, phosphorylation domain, and $\mathrm{N}$, nucleotide binding domain [33]. 
'actuator domain' of consensus sequence TGE, and the 'nucleotide binding domain' of consensus GCGINDAP (Fig. 2). The X-ray structure for the calcium ATPase of the sarcoplasmic reticulum has been solved [33] and revealed that these three domains are structurally well separated. They have been named the $\mathrm{A}, \mathrm{P}$, and $\mathrm{N}$ domains, respectively. However, the heavy metal ATPases form a distinct subfamily of the P-type ATPases [34]. Because of the conspicuous feature of the intramembranous CPC or $\mathrm{CPH}$ motif (sometimes also SPC) of heavy metal ATPases (Table 1), it has also been suggested that they are called CPx-type ATPases [35]. Phylogenetic analysis now places the P-type ATPases in various subfamilies. A website lists all members of these subfamilies of P-type ATPases (http://biobase.dk/ axe/Patbase.html).

The distinguishing CPC/CPH/SPC motifs of the CPxtype ATPases are located in the middle of a predicted membrane helix in the most conserved core structure of these ATPases. The first proline of this motif is a conserved feature of all known P-type ATPases. With the structural information available for the calcium ATPase, it has become clear that this proline is part of the calcium channel across the membrane $[33,36]$. The amino acids flanking this proline vary between enzymes and may yield information about the ion specificity. As noted by Tottey et al. [37,38], ATPases transporting $\mathrm{Cd}^{2+}, \mathrm{Zn}^{2+}, \mathrm{Pb}^{2+}$, or $\mathrm{Hg}^{2+}$ feature the membrane channel motif CPCALVIS, while in most copper translocating ATPases this motif is CPCALGLA. CopA and CopB of E. hirae feature the latter motif, in line with their proposed function in copper transport.

\subsection{Evolutionary aspects of copper ATPases}

Recently, the oldest known microfossils have been discovered in deep-sea volcanic rock, estimated to be 3.2 billion years old [39]. This suggests that hydrothermal vents have hosted the first living systems on Earth. The hot, acidic seawater encountered at these vents releases metals like iron, manganese, zinc and copper from the volcanic rock [40] and resistance to these metal ions might have been an evolutionary priority for the first life forms. High evolutionary conservation of heavy metal ATPases across phyla and the divergences of heavy metal and nonheavy metal ATPases before the division into eukaryotic and prokaryotic cells $[31,35]$ support an early evolution of heavy metal ATPases. Copper was probably not an essential trace element in early cells. Rather, it might have become a cellular constituent with the advent of a more oxidized biosphere, a process which started less than $3 \times 10^{9}$ years ago, and could thus be considered a 'modern' bioelement [41]. Cuproenzymes function almost exclusively in the metabolism of $\mathrm{O}_{2}, \mathrm{~N}_{2} \mathrm{O}$ or $\mathrm{NO}_{2}^{-}$which only became necessary with the advent of an oxidizing environment. The first heavy metal ATPases may thus have served solely in the detoxification of the cellular cytoplasm.

\subsection{Function of $\operatorname{Cop} A$}

The working model that CopA serves in copper uptake under copper-limiting conditions still rests on indirect evidence. It is based on the following two observations. First, $\triangle c o p A$ strains grow poorly in media where copper is limited by complexation with copper chelators. Secondly, $\triangle c o p A$ strains are more resistant to $\operatorname{Ag}(\mathrm{I})$ than the wildtype [42], presumably because $\mathrm{Ag}^{+}$can fortuitously enter wild-type cells via CopA. CopA endowed with a cleavable histidine tag was expressed in Escherichia coli, solubilized from cell membranes with dodecylmaltoside and purified to homogeneity by Ni-affinity chromatography [43]. Purified CopA was shown to catalyze ATP hydrolysis with and without the histidine tag. It had a $\mathrm{pH}$ optimum of 6.3 and a $K_{\mathrm{m}}$ for ATP of $0.2 \mathrm{mM}$. The activity increased three- to four-fold when the protein was reconstituted into proteoliposomes and reached $0.15 \mu \mathrm{mol} \mathrm{min} \mathrm{mg}^{-1} \mathrm{mg}^{-1}$. The enzyme formed an acylphosphate intermediate, with kinetics

Table 1

Conserved features of the membrane channel of ion pumping P-type ATPases

\begin{tabular}{|c|c|c|c|c|c|}
\hline Type & Organism & ATPase & Transported ions & $\mathrm{TM}^{\mathrm{a}}$ & Motif \\
\hline P1A & E. coli & $\mathrm{KdpB}$ & $\mathrm{K}+$ & 4 & IPTTIGGL \\
\hline P1B & Human & Menkes & $\mathrm{Cu}^{+}$ & 6 & CPCSLGLA \\
\hline P1B & E. hirae & CopA & $\mathrm{Cu}^{+} / \mathrm{Ag}^{+}$ & 6 & CPCALGLA \\
\hline P1B & E. hirae & CopB & $\mathrm{Cu}^{+} / \mathrm{Ag}^{+}$ & 6 & CPHALGLA \\
\hline P1B & Salmonella & SilP & $\mathrm{Ag}^{+}$ & 6 & CPCAMGLA \\
\hline P1B & E. coli & ZntA & $\mathrm{Cd}^{2+} / \mathrm{Zn}^{2+} / \mathrm{Pb}^{2+} / \mathrm{Hg}^{2+}$ & 6 & CPCALVIS \\
\hline P1B & Synechocystis & $\mathrm{ZiaA}$ & $\mathrm{Zn}^{2+}$ & 6 & CPCALVIS \\
\hline P1B & S. aureus & CadA & $\mathrm{Cd}^{2+}$ & 6 & CPCALVIS \\
\hline P1B & Synechocystis & CoaT & $\mathrm{Co}^{2+}$ & 6 & SPCALMAS \\
\hline $\mathrm{P} 2 \mathrm{~A}$ & Human & SERCA1 & $\mathrm{Ca}^{2+}$ & 4 & IPEGLPAV \\
\hline P2B & Human & PMCA1 & $\mathrm{Ca}^{2+}$ & 4 & VPEGLPLAV \\
\hline $\mathrm{P} 2 \mathrm{C}$ & Rat & NaK-ATPase & $\mathrm{Na}^{+} \mathrm{K}^{+}$ & 4 & VPEGLLAT \\
\hline P3A & N. crassa & PMA1 & $\mathrm{H}^{+}$ & 4 & VPVGLPAV \\
\hline P3B & E. coli & MgtA & $\mathrm{Mg}^{2+}$ & 4 & TPEMLPMI \\
\hline
\end{tabular}

${ }^{\text {a }}$ Putative transmembrane helix number. 
of formation and the effects of inhibitors and metal ions upon it supporting a function of CopA in copper transport. Vanadate, a characteristic inhibitor of P-type ATPases, exhibited $50 \%$ inhibition at $100 \mu \mathrm{M}$. These pieces of evidence strongly suggest that the CopA ATPase provides transport for both $\mathrm{Cu}^{+}$and $\mathrm{Ag}^{+}$; however, direct transport of copper in vitro has not been shown yet.

Like most heavy metal ATPases, CopA possesses an $\mathrm{N}$-terminal metal binding site with the consensus motif CxxC. Whether this motif is required for function or is dispensable, as in the related CopA ATPase of E. coli [44], is not known at present. However, mutation of the two cysteines of the $\mathrm{CxxC}$ motif to serine affected the interaction of CopA with the CopZ chaperone (see below), suggesting a function of the N-terminal metal binding motif in copper transfer from the ATPase to other cellular components.

If CopA indeed supplies copper to the cell, the direction of copper transport relative to the ATP binding site would be opposite to that postulated for most copper ATPases, and actually shown for CopB of E. hirae [45] and the human Menkes and Wilson ATPases [46,47]. However, evidence for copper transport into cells by a heavy metal ATPase has also been obtained for CtpA of Listeria monocytogenes [48,49] and CtaA of Synechocystis [37]. A screen for genes induced during infection in Staphylococcus aureus revealed the virulence gene ivi44, which encodes a protein with $50 \%$ sequence identity to CopA of E. hirae [50]. This suggests that copper is a limiting nutrient in pathogenesis and copper import becomes a cellular priority when bacteria infect a host. It would obviously be very interesting to test a $\operatorname{cop} A$ knock-out strain of $E$. hirae for its ability to infect a host. Finally, all P-type ATPases which have been studied in detail simultaneously transport ions in both directions. The NaK-ATPases exchange $\mathrm{Na}^{+}$ for $\mathrm{K}^{+}$, the $\mathrm{KH}$-ATPases exchange $\mathrm{K}^{+}$for $\mathrm{H}^{+}$and what are colloquially called Ca-ATPases are in fact CaH-ATPases. Most likely, Cu-ATPases are CuH-ATPases and it would not require major structural reorganization of the enzyme to reverse the direction of transport for these two ions.

\subsection{Function of $\mathrm{CopB}$}

CopB, like some other CPx-type ATPases, does not possess an $\mathrm{N}$-terminal $\mathrm{CxxC}$ metal binding motif. Instead, it features a histidine-rich $\mathrm{N}$-terminus which most likely also constitutes a metal binding domain. Similar histidine repeat structures were found in two Pseudomonas syringae proteins, psCopA and $\mathrm{psCopB}$, that are components of a plasmid-encoded copper resistance system [51]. PsCopA was shown to be a periplasmic protein that can bind 11 atoms of copper/monomer and was shown to serve in copper resistance by sequestering large amounts of copper in the periplasm [52].

For CopB, copper and silver transport was demon- strated directly. CopB had a $K_{\mathrm{m}}$ for $\mathrm{Cu}^{+}$of $1 \mu \mathrm{M}$ and a

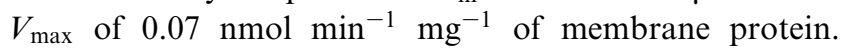
${ }^{110} \mathrm{Ag}^{+}$was transported with similar affinity and rate [45]. Since $\mathrm{Cu}^{+}$and $\mathrm{Ag}^{+}$were complexed to Tris-buffer and dithiothreitol present in the assay, the $K_{\mathrm{m}}$ values must be considered as relative only. The results obtained with membrane vesicles were further supported by ${ }^{110} \mathrm{Ag}^{+}$extrusion from whole cells, pre-loaded with this isotope [42]. These findings suggest that $\mathrm{CopB}$ functions as a $\mathrm{Cu}^{+} / \mathrm{Ag}^{+}$ATPase for the export of $\mathrm{Cu}^{+}$and $\mathrm{Ag}^{+}$in vivo, thereby serving in copper resistance $[43,45]$ (silver resistance of cells through the action of $\mathrm{CopB}$ could not be observed; the reason for this is unknown). Maximal transport was observed at $\mathrm{pH}$ 6. Biochemical experiments with purified CopB in reconstituted phospholipid vesicles [53] showed that the enzyme is also vanadate sensitive $\left(I_{50}=100 \mu \mathrm{M}\right)$, has a $K_{\mathrm{m}}$ for ATP of $0.5 \mathrm{mM}$ and a $V_{\max }$ for ATP hydrolysis of $1.3 \mu \mathrm{mol} \mathrm{min}-1 \mathrm{mg}^{-1}$ [54].

In an ion-motive ATPase, ATP hydrolysis and transport must be coupled, i.e. there should not be ATP hydrolysis in the absence of the ion(s) transported by this ATPase. Purified CopB exhibited maximal ATPase activity in the absence of added copper ions. Presumably, this was due to the presence of sufficient contaminating copper for full ATPase activity. However, attempts to remove residual copper with standard copper chelators such as bicinchoninic acid or bathocuproine and thereby inhibit $\mathrm{CopB}$ did not meet with success. Only tetrathiomolybdate, which strongly interacts with copper and has been used to treat patients with Wilson disease [7,55], could efficiently scavenge residual copper in purified $\mathrm{CopB}$ preparations and reversibly inhibit CopB [6]. These experiments suggested that CopB has a very low $K_{\mathrm{m}}$ for copper in the range of 30 $\mathrm{nM}$ and advocate tetrathiomolybdate as new tool for the study of copper ATPases. Silver(I), which is also transported by CopB, could similarly activate the ATPase activity of CopB [6]. On mechanistic grounds, it appears unlikely that CopB could transport either monovalent or divalent heavy metal ions. So other heavy metals like zinc, lead, cadmium, mercury or lead, which do not form stable monovalent ions, are unlikely to be substrates of CopB.

\subsection{CopB as a model for Menkes and Wilson ATPase}

CopB is massively overexpressed in an E. hirae mutant strain deficient in the CopY repressor (see below). Following solubilization from membranes with dodecylmaltoside, it can be purified by Ni-affinity chromatography. The histidine-rich N-terminus of CopB thereby acts as an 'endogenous' histidine tag [53]. This convenient purification procedure of the wild-type enzyme makes CopB readily accessible to biochemical characterization. E. hirae CopB is sufficiently related to the human Menkes and Wilson ATPases that the effect of mutations in the human enzymes can be tested with CopB. It was used to test the impact of some of the mutations occurring in the highly 


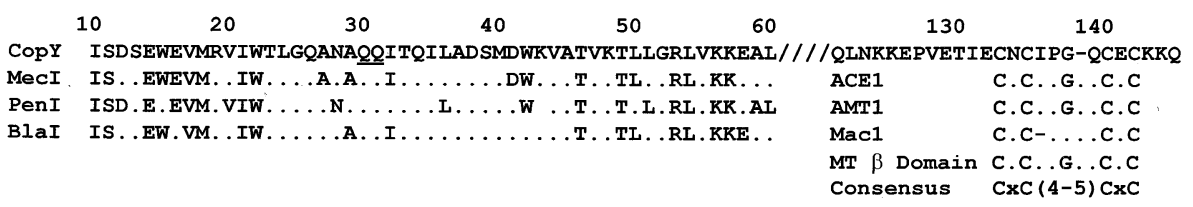

Fig. 3. Bi-partite structure of the CopY repressor. The N-terminus of CopY exhibits sequence similarity to the DNA binding domains of $\beta$-lactamase repressor proteins of Gram-positive bacteria, while the $\mathrm{C}$-terminus contains a cysteine consensus motif found in copper and zinc binding proteins. In analogy to the phage $\lambda$ cro repressor, the QQ motif (underlined) near the N-terminus of CopY could tightly interact with an ACA triplet on the promoter. The amino acid numbering is for CopY. The slashes substitute the omitted region of CopY, dots stand for non-identical amino acids, and hyphens indicate missing amino acids. See text for additional detail.

conserved motifs. A C396S mutation was introduced into the conserved CPC motif of CopB to mimic the C1000R mutation in ATP7A, identified in a Menkes patient. This mutant enzyme was not able to reverse the copper sensitive phenotype of a CopB knock-out strain. The purified C396S mutant enzyme did not show any ATPase activity [54]. Similarly, the most frequent Wilson disease mutation H1069Q was introduced into CopB as a H480Q mutation. H480 is part of the HP motif, a motif of unknown function. It is universally conserved in heavy metal ATPases and is also present in a group of related copper proteins, including CopA from $P$. syringae, a similar protein from Xanthomonas campestris, laccase from four different fungi, and ascorbate oxidase from cucumber [56]. The H480Q mutation eliminated copper transport by $\mathrm{CopB}$ as tested in vivo, but the purified protein still exhibited residual ATPase activity. The mutation did not affect the $K_{\mathrm{m}}$ for ATP, but reduced $V_{\max }$ more than 50-fold [54]. The result suggested that the HP motif is not involved in ATP binding, even though the site is very near the ATP binding site. Clearly, site-directed mutagenesis of CopB offers an avenue for the analysis of structure-function relationships of broader significance in copper ATPases.

\section{Regulation of the cop operon by the CopY repressor and the CopZ chaperone}

Various mechanisms of regulation of copper resistance and tolerance have evolved in different bacterial species. Examples are the plasmid-borne cop system of $P$. syringae [57] and the pco system of E. coli. They are regulated by two-component regulatory systems, which communicate via series of phosphorylation/dephosphorylation reactions [58]. Transcription of the $\operatorname{cop} A$ gene in E. coli on the other hand is regulated by the copper-responsive, MerR-like activator, CueR $[59,60]$. The cop operon of E. hirae is regulated by the copper-responsive repressor CopY, a protein of 145 amino acids [61]. By database searching, repressors similar to CopY can only be identified in Gram-positive bacteria closely related to E. hirae. This contrasts with the very high evolutionary conservation of the copper ATPases across phyla (see above). It could be hypothesized that ancient copper ATPases were expressed constitutively and only served in detoxification of the cytoplasm. With the advent of an oxidizing environment, copper became a component of redox enzymes and therefore had to be carefully regulated. This could have led to the parallel evolution of different regulatory systems in various organisms.

\subsection{In vivo regulation of the cop operon}

A $\Delta \operatorname{cop} Y$ deletion strain led to constitutive overexpression of CopA and CopB, while a $\Delta \operatorname{cop} Z$ strain exhibited reduced levels of expression. This led to the initial suggestion that CopY was a repressor and CopZ was an activator [61]. Given the model that CopA functions in copper uptake and CopB in its extrusion, it would seem paradoxical that both genes are under the same control. Though this could be a safety mechanism: if the cells express only the importer, CopA, under copper-limiting conditions, they would become vulnerable to copper toxicity in case of a sudden increase of ambient copper. Addition, as well as complexation, of ambient copper led to the induction of the operon. This bi-phasic regulation would support a function of the cop genes in both, copper uptake and secretion. The lowest induction of the genes was in standard growth medium containing about $1 \mu \mathrm{M}$ copper and full induction was obtained with $2 \mathrm{mM}$ copper in the medium. The operon was also induced by $5 \mu \mathrm{M} \mathrm{Cd}^{2+}$ or $\mathrm{Ag}^{+}$[62]. According to the current concept, CopY is a copper-responsive repressor: in the $\mathrm{Zn}^{2+}$ form, it is bound to the promoter and suppresses transcription. CopZ can donate copper to CopY, thereby releasing it from the DNA and allowing expression of the downstream cop genes.

\subsection{Structure of the Cop $Y$ repressor}

The structure of CopY is bi-partite: the N-terminal half of the protein exhibits around $30 \%$ sequence identity to bacterial repressors of $\beta$-lactamases, such as MecI of S. aureus (accession BAA82218), PenI of Bacillus licheniformis (accession B28183), or BlaI from an S. aureus transposon Tn552 (accession CAA36951; Fig. 3) [63-65]. For PenI, there is evidence that the N-terminal portion of the protein is the DNA binding domain [66]. The CopY N-terminus also features a QQ motif. For the phage $\lambda$ cro repressor and phage 434 repressor, a QQ motif in similar positions has been shown to tightly interact with 
an ACA triplet of the DNA binding sites [67]. Support for a similar interaction of the QQ motif of CopY stems from the observation that mutation of ACA to TCA in the CopY DNA binding sites abolishes CopY-DNA interaction in vitro (see below).

In the C-terminal half of CopY, there are multiple cysteine residues, arranged as $\mathrm{CxCx}_{4} \mathrm{CxC}$. The consensus motif $\mathrm{CxCx}_{4-5} \mathrm{CxC}$ is also present in yeast ACE1 and AMT1, which are copper-responsive transcriptional activators for metallothionein [68,69], in Mac1, a transcription factor for the $\mathrm{Ctr} 1$ and $\mathrm{Ctr} 3$ copper transporters of $S$. cerevisiae [70], and in the N-terminal $\beta$-domain of human metallothionein-2 [71]. As experimental work has shown, the $\mathrm{CxCx}_{4} \mathrm{CxC}$ motif is the site where either one $\mathrm{Zn}^{2+}$ or two $\mathrm{Cu}^{+}$can be bound. By crosslinking experiments and analytical gel filtration, it could be shown that the CopY repressor is, like most repressors, a homodimer [72].

\subsection{Function of the Cop Y repressor}

Binding of CopY to an inverted repeat sequence upstream of the cop $\mathrm{Y}$ gene has been demonstrated in vitro [72]. DNase footprints showed that the CopY dimer protects two discrete sites of 27 and $28 \mathrm{bp}$, identified in the region between -70 and -11 . CopY-DNA interaction occurred in two steps with two discrete apparent half-maximal DNA binding constants. $\mathrm{Cu}^{+}$released $\mathrm{CopY}$ from the promoter with an apparent half-binding constant for $\mathrm{Cu}(\mathrm{I})$ of $20 \mu \mathrm{M}$. Promoter mutations at A-61T and A-30T abolished the binding of CopY to one or the other binding site, in agreement with the postulated strong interaction of a QQ motif in CopY with an ACA motif in the promoter.

To study the effect of these promoter mutations in vivo, a plasmid-borne expression system encoding a truncated CopB ATPase which was non-functional, but detectable with a specific antibody, was employed. This system was developed due to the lack of success in using $\beta$-galactosidase or chloramphenicol acetyltransferase as reporter genes in E. hirae. Mutation of both A-61T and A-30T, but not either alone, abolished the binding of CopY and led to approximately 1000-fold hyperinduction of the promoter [73]. Interestingly, induction by chelation of copper was not affected by these promoter mutations, which suggests that the induction of the cop operon by copper starvation does not proceed via release of CopY from the DNA. The mechanism could involve other elements, such as a sigma factor or a stress response regulator.

In vitro studies showed that CopY binds to DNA as a $\mathrm{Zn}$ (II)CopY complex. For the release of CopY from the DNA, two $\mathrm{Cu}(\mathrm{I})$ can displace the $\mathrm{Zn}(\mathrm{II})$ in CopY. $\mathrm{Cu}(\mathrm{I})$ can be donated to CopY by $\mathrm{Cu}(\mathrm{I}) \mathrm{CopZ}$ or suitable copper(I) complexes, such as $\mathrm{Cu}(\mathrm{I})$-acetonitrile [74]. The $\mathrm{Cu}(\mathrm{I})_{2} \mathrm{CopY}$ complex exhibits luminescence, implying that $\mathrm{Cu}(\mathrm{I})$ is sequestered in an environment where it is protected from solvent. X-ray absorption studies suggested a mixture of two- and three-coordinate copper in $\mathrm{Cu}(\mathrm{I})$ -
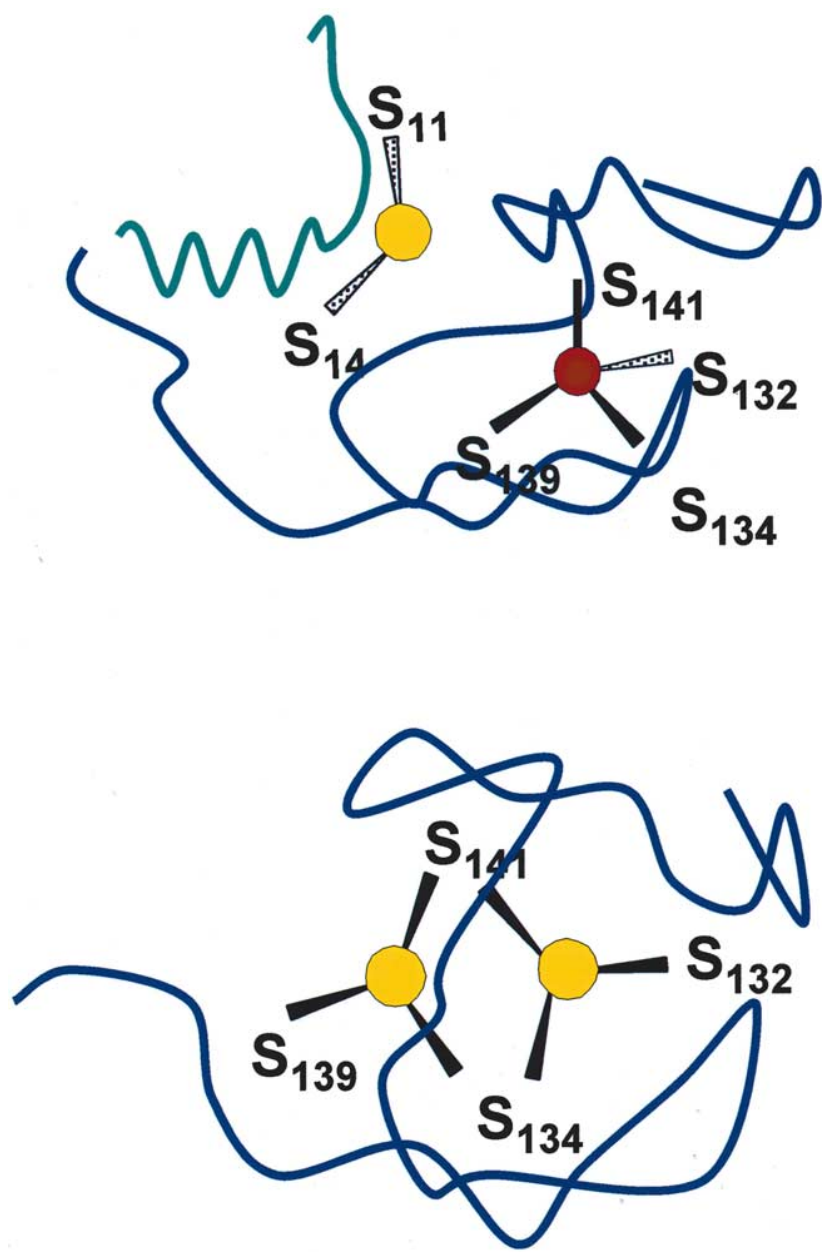

Fig. 4. Coordination of copper and zinc in CopY and CopZ. Top: CopZ (green line) donates two-coordinate copper(I) ions to CopY (blue line), which contains a four-coordinate zinc(II). Bottom: $\mathrm{Zn}$ (II) was displaced by two copper(I) ions, which now form a compact binuclear $\mathrm{Cu}(\mathrm{I})$-thiolate core in the $\mathrm{CxCx}_{4} \mathrm{CxC}$ binding site of CopY.

CopZ, but a purely three-coordinate copper coordination with a $\mathrm{Cu}-\mathrm{Cu}$ interaction for $\mathrm{Cu}(\mathrm{I})_{2} \mathrm{CopY}$. The latter coordination is consistent with the formation of a compact binuclear $\mathrm{Cu}(\mathrm{I})$-thiolate core in the $\mathrm{CxCx}_{4} \mathrm{CxC}$ binding motif of CopY (Fig. 4) [75].

The displacement of zinc by copper was monitored by the spectral shift of the absorbance maximum from 412 to $500 \mathrm{~nm}$ of 2,4-pyridylazoresorcinol upon zinc binding [76]. Two copper(I) ions were required to release the single zinc(II) ion bound per CopY monomer. It is plausible that the $\mathrm{Cu}(\mathrm{I})$ ions are being sequestered in a $\mathrm{Cu}(\mathrm{I})$-thiolate cluster as found in the $\mathrm{Cu}(\mathrm{I})$-regulated transcription factor ACE1 and the metallothioneins [69]. The inability of the displaced $\mathrm{Zn}(\mathrm{II})$ to bind to CopZ suggests that the metal binding site in CopZ is specific for $\mathrm{Cu}(\mathrm{I})$. The combined findings of X-ray absorption spectroscopy and luminescence studies show that CopY binds either one zinc ion or two copper ions to the $\mathrm{CxCx}_{4} \mathrm{CxC}$ motif, located in a protected, solvent-inaccessible core [76,77].

The specificity of copper transfer between $\mathrm{Cu}(\mathrm{I}) \mathrm{CopZ}$ 


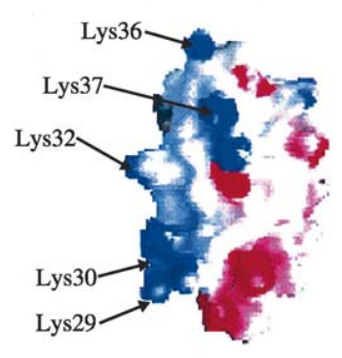

CopZ

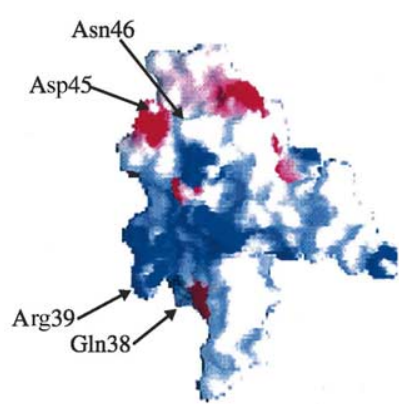

$\mathrm{MNKr} 2$

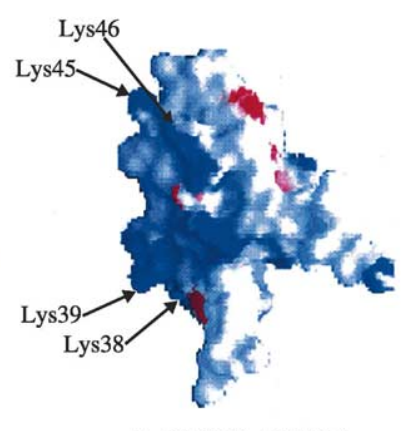

MNKr2K4

Fig. 5. Surface charge and arrangement of lysine residues of CopZ, MNKr2 and MNKr2K4. Electrostatic surfaces were created with GRASP and were overlaid onto the NMR structures of CopZ, MNKr2 and a model of MNKr2K4 [84] (Jones and Dameron, unpublished). MNKr2K4 was modeled from the average structure of MNKr2 using SYBYL (Tripos). Blue areas are positively charged and red areas negatively. The residues replaced in $\mathrm{MNKr} 2$ to create a charged face resembling that of CopZ in the gain-of-function mutant MNKr2K4 are labeled.

and CopY was dependent on electrostatic interactions. Relative copper binding affinities of the proteins were investigated using the chelator diethyldithiocarbamic acid. The findings suggested that CopY has a higher affinity for copper than CopZ. However, this affinity difference does not appear to be the sole factor in the copper exchange: a charge-based interaction between the two proteins is required for the transfer reaction to proceed. $\mathrm{Cu}(\mathrm{I}) \mathrm{MNK}$ 2, the second CopZ-like metal binding domain of the human Menkes ATPase, is not able to donate copper to CopY. It could be shown that this was due to the very different electrostatic surface of MNKr2. A gainof-function mutant of MNKr2 could be created. In this mutant protein, $\mathrm{MNKr} 2 \mathrm{~K} 4$, four amino acids were mutated to lysines to mimic the electrostatic surface of CopZ (Fig. 5). Cu-MNKr2K4 functioned in $\mathrm{Cu}^{+}$transfer to CopY as well as $\mathrm{Cu}-\mathrm{CopZ}$. This demonstrated the necessity of four lysine residues on the chaperone for the interaction with CopY. Taken together, these results suggest a mechanism for copper exchange between CopZ and CopY which involves specific protein-protein interaction.

Available data suggest that a similar regulatory mechanism controls the expression of the CadA ATPase, which confers cadmium resistance to $E$. coli. The CadC repressor was shown in vitro to bind to the $c a d$ operator/promoter. $\mathrm{Cd}^{2+}, \mathrm{Bi}^{3+}$, and $\mathrm{Pb}^{2+}$ caused the release of CadC from DNA, as shown in band shift experiments [78]. However, the CadC repressor does not exhibit sequence similarity to CopY and whether displacement of zinc from CadC is involved in the process was not shown.

\section{The family of copper chaperones}

Copper chaperones are members of a diverse group of proteins involved in the intracellular delivery of copper. Studies in yeast suggest that chaperones are required in vivo because intracellular copper concentrations are extremely low, requiring direct protein-protein interaction for copper delivery to copper requiring enzymes [79]. Well studied copper chaperones are the yeast and human chaperones for superoxide dismutase (CCS), delivering copper specifically to superoxide dismutase [80]. Other chaperones serve in the delivery of copper to cytochrome $c$ oxidase (Cox17, Cox19, Sco1, Sco2), to the Menkes/Wilson copper ATPase in humans (Atox1), or the corresponding CCC2 copper ATPase in yeast (Atx1; see [81] for review). Atx 1 and CopZ belong to the same family of $8-\mathrm{kDa}$ copper chaperones, which are present in cells of all phyla.

Surprisingly, it was found that the N-termini of most heavy metal ATPases also contain domains that are similar to Atx1 and CopZ [82]. These domains occur in one or two copies in microbial enzymes through to six copies in the human Menkes and Wilson copper ATPases. While the role of these modules in these proteins is still poorly defined, we now have a detailed understanding of the structure and function of Atx1- or CopZ-like domains.

\subsection{Structure of CopZ}

Detailed structural studies have shown that members of the homologous family of CopZ-like chaperones have very similar folds [83]. The structure of apo-CopZ has been determined by nuclear magnetic resonance (NMR) $[84,85]$. The CopZ fold consists of four $\beta$-strands forming an antiparallel $\beta$-sheet, situated below two $\alpha$-helices (structure 1CPZ in the PDB Database). This arrangement of secondary structure elements is characteristic of the ferredoxin-like proteins and is known as an 'open-faced $\beta$-sandwich'. The two copper binding residues, Cys-11 and Cys-14, of the CxxC motif are located in a loop between $\beta 1$ and $\alpha 1$, binding copper on an exposed position at one end of the molecule. The exposed copper binding site sets copper chaperones apart from the cuproenzymes known hitherto, which have the copper buried deeply inside the protein. The exposed copper on chaperones must be a functional requirement, facilitating reception and donation of copper. 


\subsection{Interaction of the CopZ chaperone with the CopA ATPase}

As discussed above, CopZ delivers copper to the CopY repressor. By using surface plasmon resonance analysis (on a Biacore apparatus) it could be shown that CopZ also interacts with the CopA copper ATPase, which could be the site of copper loading of CopZ [86]. Interaction between CopZ in solution with CopA immobilized on the surface of the sensor chip was studied in detail. The association rate $k_{\mathrm{a}}$ was only slightly affected by copper(I) and maximally exhibited a two-fold change compared to copper-unsupplemented conditions. In contrast, the dissociation rate $k_{\mathrm{d}}$ was strongly influenced by added copper and was decreased up to 15 -fold by copper(I). Copper could thus modulate the interaction of CopZ with CopA.

To test if the CxxC metal binding motif of CopA plays a key role in the CopZ-CopA interaction, such as by copper bridging, a CopA mutant which had the cysteine residues of the $\mathrm{CxxC}$ motif mutated to serine residues (SxxS) was constructed. CopZ still strongly bound to the CopA with the SxxS motif, but the interaction was no longer significantly influenced by copper; all association and dissociation rate constants resembled those observed for wild-type CopA in the absence of added copper. Thus, the $\mathrm{CxxC}$ motif increases binding of $\mathrm{CopZ}$ to $\mathrm{CopA}$ in the presence of copper. However, it is not the guiding element for the interaction of CopZ with CopA. Direct proteinprotein interaction must occur. The positively charged surface on CopZ could be interacting with a negatively charged surface on CopA to establish a protein contact. Such an interaction has been shown to take place between the homologous yeast proteins, the CCC2 ATPase and the Atx 1 chaperone [87].

If CopA is indeed the site of copper loading of CopZ, copper could be transferred from CopA to CopZ by a ligand transfer mechanism (Fig. 6). Such a mechanism
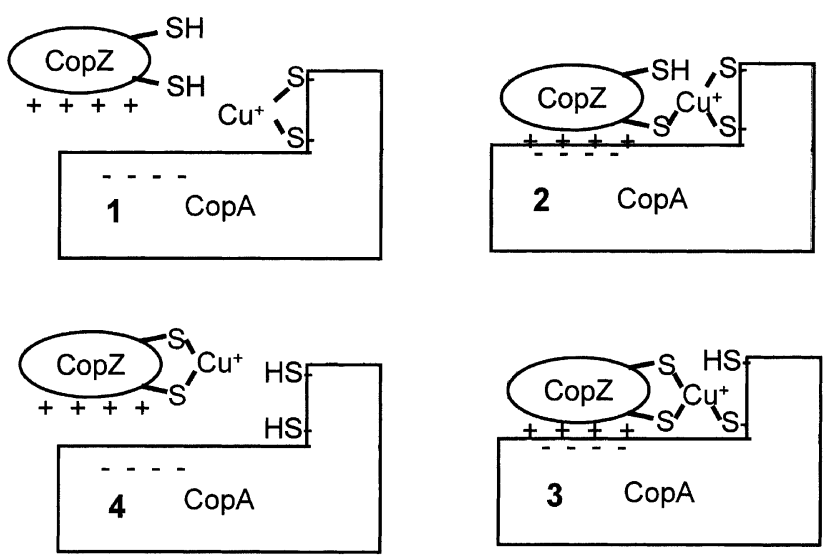

Fig. 6. Hypothetical ligand transfer mechanism for copper transfer from CopA to CopZ. Copper could be transferred from the CopA ATPase to the CopZ chaperone by the successive transfer of thiol ligands, as shown by the sequence of events in illustrations 1-4. The positively charged surface on CopZ could be interacting with a negatively charged surface on CopA to establish a protein contact. had originally been suggested by Brown et al. for mercury transfer between the MerP mercury chaperone and the mercury transporter [88]. The same model was later adopted by Pufahl et al. for copper transfer from the yeast Atx1 chaperone to the copper ATPase [89]. While plausible, such a ligand transfer mechanism remains to be proven in detail.

\subsection{Proteolytic regulation of $\operatorname{Cop} Z$}

It was observed that CopZ of E. hirae is more labile under high copper stress. Levels of copZ mRNA increased with increasing ambient copper levels and reached a 1000fold induction at $0.25 \mathrm{mM}$ copper [90]. However, CopZ expression increased only up to $0.5 \mathrm{mM}$ copper and declined at higher copper concentrations, as shown by Western blotting of crude cell lysates. It could be shown that CopZ overexpression is toxic to cells. First, growth of a strain overexpressing CopZ was inhibited by ambient copper in excess of $0.1 \mathrm{mM}$ and was abolished by $1.5 \mathrm{mM}$ copper, while growth of wild-type $E$. hirae was not markedly affected by this copper concentration. Secondly, CopZ overexpression made $E$. hirae more sensitive to oxidative stress, such as growth in the presence of $\mathrm{H}_{2} \mathrm{O}_{2}$ or paraquat.

Proteolysis of CopZ could be demonstrated in vitro with cytosolic extracts and purified CopZ. Interestingly, apo-CopZ was significantly more resistant to in vitro degradation than $\mathrm{Cu}-\mathrm{CopZ}$. The more rapid degradation of $\mathrm{Cu}-\mathrm{CopZ}$ is in line with its proposed toxicity. Copper bound to CopZ is solvent-exposed [74] and this copper can thus participate in Fenton-type reactions and lead to the generation of reactive hydroxyl radicals and cell damage.

The protease responsible for CopZ degradation was apparently constitutive, but stimulated by copper(I) or $\mathrm{Ag}(\mathrm{I})$, a $\mathrm{Cu}(\mathrm{I})$ mimetic. The serine protease inhibitors $p$-phenylmethylsulfonyl fluoride (PMSF) and $p$-aminobenzamidine inhibited the degradation of CopZ, while $N$ - $\alpha$ - $p$-tosyl-Llysine chloromethyl ketone and $N$-tosyl-L-phenylalanine chloromethyl ketone, which are also serine protease inhibitors, were without effect. The metallo-proteinase inhibitor $o$-phenanthroline also did not inhibit CopZ degradation. Clearly, the protease degrading CopZ is a serine-type protease. On zymograms, the protease was tentatively identified as a protein of $58 \mathrm{kDa}[91,92]$. Fig. 7 summarizes the regulation of the $E$. hirae cop operon at the current level of understanding. See legend for detail.

Proteolysis as a regulatory mechanism of protein expression has received much less attention than transcriptional and translational regulation [93,94]. There are, however, a few examples of proteolysis linked to metal ion metabolism. In Saccharomyces cerevisiae, copper-induced degradation was described for the copper importer Ctr1 [95], as well as for the transcription factor Macl which is also involved in high affinity copper uptake [96]. An interesting 
low copper
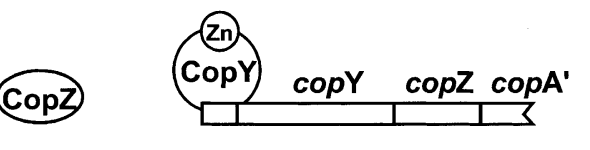

high copper

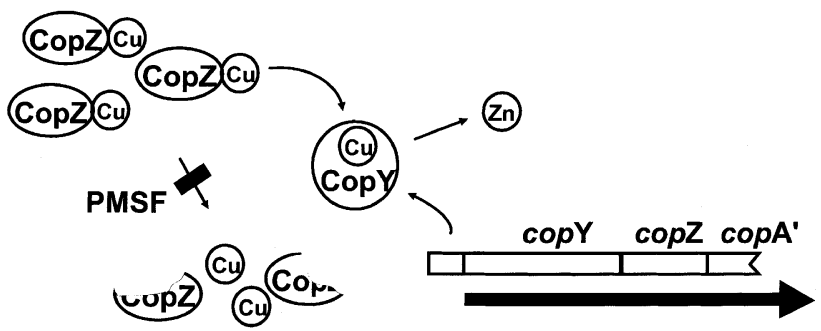

Fig. 7. Model of copper regulation in E. hirae. At physiological copper levels (low copper), $\mathrm{Zn}$ (II)CopY is bound to the promoter and transcription of the cop operons is turned down. If copper is excessive (high copper), $\mathrm{Cu}(\mathrm{I}) \mathrm{CopZ}$ donates copper to the $\mathrm{Zn}$ (II)CopY repressor, which then loses the bound zinc and dissociates from the DNA, allowing transcription to proceed. To prevent cell damage, the level of $\mathrm{Cu}(\mathrm{I}) \mathrm{CopZ}$ is not allowed to rise beyond a certain level and excess $\mathrm{Cu}(\mathrm{I}) \mathrm{CopZ}$ is degraded by a copper-activated protease which can be inhibited by PMSF.

proteolytic process is the degradation of apo-plastocyanin under copper starvation in the green algae Chlamydomonas reinhardtii. Presumably, this serves to preserve copper for use by other, indispensable cuproenzymes [97]. None of the proteases involved in these processes has so far been identified. Copper-induced proteolysis adds yet another level of complexity to the copper homeostatic process.

\section{Extracellular copper reductase}

Current evidence suggests that copper(I) is the species being transported by copper ATPases or Ctr1-like copper transporters. Yet, copper(I) ions are insoluble in free form at physiological $\mathrm{pH}$ and in standard bacteriological media. This suggests that there must be copper ligands and copper reductases involved in the copper homeostatic process. In $E$. coli it was shown that the copper(II) ions which enter the periplasm can be reduced to copper(I) by the reductase NDH-2 [98,99]. When E. hirae is grown in media supplemented with $6 \mathrm{mM}$ copper(II), the blue color of the media is lost in several hours due to the presence of copper reductase activity of extracellular or membrane bound nature [20,100]. An energy (glucose) dependent copper-reducing activity could also be measured with washed $E$. hirae cells. The activity was strongly inhibited by $\mathrm{Hg}^{2+}$, with an $I_{50}$ of $1 \mu \mathrm{M}$, and much less by $\mathrm{Ag}^{+}$with an $I_{50}$ of $50 \mu \mathrm{M}$. Other metals, such as nickel(II), tin(II), cadmium(II), platinum(I) and platinum(II), had no significant inhibitory effects at concentrations as high as 100 $\mu$ M. Platinum(II) was shown to be an inhibitor of the yeast copper and iron reductase Frelp with an $I_{50}$ of 50 $\mu \mathrm{M}$ [101] which suggests a different biochemical mechanism of copper reduction by the yeast and the enterococcal enzyme. However, cloning of the $E$. hirae copper reductase has so far not met with success and more work needs to be done in this field.

\section{Concluding remarks}

The homeostatic control of copper is a formidable problem for cells and its study has met with difficulties. In this context, the E. hirae model system has, through its simplicity and accessibility, proven to be ideally suited to address fundamental questions of copper homeostasis. The striking homology of major components of copper homeostasis, such as the copper ATPases or the CopZlike copper chaperones, across phyla shows that copper metabolism has evolved early and has been highly conserved through evolution, from bacteria to humans. Insight gained into the mechanism of bacterial copper homeostasis will thus be widely applicable. Understanding how cells deal with copper is fundamental to understanding copper's role in health and disease. For example, knowledge is still lacking on the minimal required copper intake for humans, as well as the maximal level of copper intake that is still safe.

There is increasing concern about copper contamination of the environment through the use of copper in agricultural pest control, the addition of copper to animal feed, or from the wash-out of copper pipes and roofs. Bacteria are the major players in determining the fate of materials in the environment. Acidithiobacillus ferrooxidans, Leptospirillum ferrooxidans and species of the genus Acicdiphillum were found to be involved in biooxidation of copper sulfide under acidic conditions (bioleaching) and these organisms are extensively used in biogeotechnology [102]. One potentially important impact of bacterial action on environmental copper is copper reduction at the cell surface. The biologically relevant form of copper, i.e. the form that is taken up by cells and transported intracellularly, is copper(I). This may be the primary reason why cells are endowed with copper reductase activity. The known extracellular copper reductase activities, such as those observed in E. hirae and yeast, are far in excess of cellular needs and will have a major impact on the speciation of copper in the environment. Understanding bacterial copper homeostasis at the molecular level will aid definition of the impact of bacteria on environmental copper.

\section{Acknowledgements}

We are grateful to the members of the Solioz lab for their contributions and their enthusiasm. Financial support was received from the Swiss National Foundation, Grant 31-68075.02, and from the International Copper Association. 


\section{References}

[1] Tylecote, R.F. (1992) A History of Metallurgy. Institute of Materials, London.

[2] Karlin, K.D. (1993) Metalloenzymes, structural motifs, and inorganic models. Science 261, 701-708.

[3] Bell, P.F., Chen, Y., Potts, W.E., Chaney, R.L. and Angle, J.S. (1991) A reevaluation of the $\mathrm{Fe}(\mathrm{III}), \mathrm{Ca}(\mathrm{II}), \mathrm{Zn}(\mathrm{II})$, and proton formation constants of 4,7-diphenyl-1,10-phenanthrolinedisulfonate. Biol. Trace Elem. Res. 30, 125-144.

[4] Hemmerich, P. and Sigwart, C. (1963) $\mathrm{Cu}\left(\mathrm{CH}_{3} \mathrm{CN}\right)_{2}^{+}$, ein Mittel zum Studium homogener Reaktionen des einwertigen Kupfers in wässriger Lösung. Experientia 19, 488-489.

[5] McPhail, D.B. and Goodman, B.A. (1984) Tris buffer - a case for caution in its use in copper-containing systems (letter). Biochem. J. 221, 559-560.

[6] Bissig, K.D., Voegelin, T.C. and Solioz, M. (2001) Tetrathiomolybdate inhibition of the Enterococcus hirae CopB copper ATPase. FEBS Lett. 507, 367-370.

[7] Brewer, G.J., Johnson, V., Dick, R.D., Kluin, K.J., Fink, J.K. and Brunberg, J.A. (1996) Treatment of Wilson disease with ammonium tetrathiomolybdate. II. Initial therapy in 33 neurologically affected patients and follow-up with zinc therapy. Arch. Neurol. 53, 10171025.

[8] Andrews, N.C. (2002) Metal transporters and disease. Curr. Opin. Chem. Biol. 6, 181-186.

[9] Yoshida, Y., Furuta, S. and Niki, E. (1993) Effects of metal chelating agents on the oxidation of lipids induced by copper and iron. Biochim. Biophys. Acta 1210, 81-88.

[10] Cadenas, E., Brigelius, R., Akerboom, T. and Sies, H. (1983) Oxygen radicals and hydroperoxides in mammalian organs: aspects of redox cycling and hydrogen peroxide metabolism. In: 34. Kolloquium Moosbach; Biological Oxidations (Sund, H. and Ullrich, V., Eds.), pp. 288-310. Springer, Berlin.

[11] Klotz, L.-O. and Weser, U. (1998) Biological chemistry of copper compounds. In: Copper and Zinc in Degenerative Diseases (Rainsford, K.D., Ed.), pp. 19-46. Kluwer Academic Publishers, Dordrecht.

[12] Fahey, R.C., Brown, W.C., Adams, W.B. and Worsham, M.B. (1978) Occurrence of glutathione in bacteria. J. Bacteriol. 133, 1126-1129.

[13] Newton, G.L., Arnold, K., Price, M.S., Sherrill, C., Delcardayre, S.B., Aharonowitz, Y., Cohen, G., Davies, J., Fahey, R.C. and Davis, C. (1996) Distribution of thiols in microorganisms: mycothiol is a major thiol in most actinomycetes. J. Bacteriol. 178, 1990-1995.

[14] Freedman, J.H., Ciriolo, M.R. and Peisach, J. (1989) The role of glutathione in copper metabolism and toxicity. J. Biol. Chem. 264, 5598-5605.

[15] Kocha, T., Yamaguchi, M., Ohtaki, H., Fukuda, T. and Aoyagi, T. (1997) Hydrogen peroxide-mediated degradation of protein: different oxidation modes of copper- and iron-dependent hydroxyl radicals on the degradation of albumin. Biochim. Biophys. Acta 1337, 319-326.

[16] Cha, J.S. and Cooksey, D.A. (1991) Copper resistance in Pseudomonas syringae mediated by periplasmic and outer membrane proteins. Proc. Natl. Acad. Sci. USA 88, 8915-8919.

[17] Solioz, M. and Bissig, K.-D. (1998) How (deficient) copper causes illness. Schweiz. Med. Wochenschr. 128, 1175-1180.

[18] Lu, Z.H., Cobine, P., Dameron, C.T. and Solioz, M. (1999) How cells handle copper: A view from microbes. J. Trace Elem. Exp. Med. 12, 347-360.

[19] Solioz, M., Odermatt, A. and Krapf, R. (1994) Copper pumping ATPases: common concepts in bacteria and man. FEBS Lett. 346, $44-47$.

[20] Wunderli-Ye, H. and Solioz, M. (1999) Copper homeostasis in Enterococcus hirae. Adv. Exp. Med. Biol. 448, 255-264.

[21] Solioz, M. and Stoyanov, J.V. (2002) How cells deal with copper: a lesson from bacteria. In: Macro and Trace Elements (Anke, M.,
Müller, R., Schäfer, U. and Stoeppler, M., Eds.), pp. 485-492. Schubert-Verlag, Leipzig.

[22] Odermatt, A., Suter, H., Krapf, R. and Solioz, M. (1992) An ATPase operon involved in copper resistance by Enterococcus hirae. Ann. N.Y. Acad. Sci. 671, 484- 486.

[23] Chelly, J., Tumer, Z., Tonnesen, T., Petterson, A., Ishikawa Brush, Y., Tommerup, N., Horn, N. and Monaco, A.P. (1993) Isolation of a candidate gene for Menkes disease that encodes a potential heavy metal binding protein. Nat. Genet. 3, 14-19.

[24] Mercer, J.F.B., Livingston, J., Hall, B., Paynter, J.A., Begy, C., Chandrasekharappa, S., Lockhart, P., Grimes, A., Bhave, M., Siemieniak, D. and Glover, T.W. (1993) Isolation of a partial candidate gene for Menkes disease by positional cloning. Nat. Genet. 3, 20-25.

[25] Vulpe, C., Levinson, B., Whitney, S., Packman, S. and Gitschier, J. (1993) Isolation of a candidate gene for Menkes disease and evidence that it encodes a copper-transporting ATPase. Nat. Genet. 3, 7-13.

[26] Tanzi, R.E., Petrukhin, K., Chernov, I., Pellequer, J.L., Wasco, W., Ross, B., Romano, D.M., Parano, E., Pavone, L. and Brzustowicz, L.M. (1993) The Wilson disease gene is a copper transporting ATPase with homology to the Menkes disease gene. Nat. Genet. 5, 344 350.

[27] Bull, P.C., Thomas, G.R., Rommens, J.M., Forbes, J.R. and Cox, D.W. (1993) The Wilson disease gene is a putative copper transporting P-type ATPase similar to the Menkes gene. Nat. Genet. 5, 327337.

[28] Solioz, M. (2001) Bacterial copper transport. In: Microbial Transport Systems (Winkelmann, G., Ed.), pp. 361-376. Wiley, Weinheim.

[29] Bissig, K.-D., Wunderli-Ye, H. and Solioz, M. (2000) Copper Homeostasis in Enterococcus hirae: Pumps, Repressor, Chaperone, pp. 133-136. John Libbey Eurotext, Paris.

[30] Solioz, M. (1998) Copper homeostasis by CPX-type ATPases, the subclass of heavy metal P-type ATPases. In: Ion Pumps (Andersen, J.P., Ed.), pp. 167-203. JAI Press, London.

[31] Lu, Z.H. and Solioz, M. (2002) Bacterial copper transport. Adv. Protein Chem. 60, 93-121.

[32] Pedersen, P.L. and Carafoli, E. (1987) Ion motive ATPases. I. Ubiquity, properties, and significance to cell function. Trends Biochem. Sci. 12, 146-150.

[33] Toyoshima, C., Nakasako, M., Nomura, H. and Ogawa, H. (2000) Crystal structure of the calcium pump of sarcoplasmic reticulum at $2.6 \AA$ resolution. Nature 405, 647-655.

[34] Lutsenko, S. and Kaplan, J.H. (1995) Organization of P-type ATPases: Significance of structural diversity. Biochemistry 34, 1560715613.

[35] Solioz, M. and Vulpe, C. (1996) CPx-type ATPases: a class of P-type ATPases that pump heavy metals. Trends Biochem. Sci. 21, 237-241.

[36] Toyoshima, C. and Nomura, H. (2002) Structural changes in the calcium pump accompanying the dissociation of calcium. Nature $418,605-611$.

[37] Tottey, S., Rich, P.R., Rondet, S.A. and Robinson, N.J. (2001) Two Menkes-type atpases supply copper for photosynthesis in Synechocystis PCC 6803. J. Biol. Chem. 276, 19999-20004.

[38] Rutherford, J.C., Cavet, J.S. and Robinson, N.J. (1999) Cobalt-dependent transcriptional switching by a dual-effector MerR-like protein regulates a cobalt-exporting variant CPx-type ATPase. J. Biol. Chem. 274, 25827-25832.

[39] Rasmussen, B. (2000) Filamentous microfossils in a 3,235-millionyear-old volcanogenic massive sulphide deposit. Nature 405, 676-679.

[40] Zierenberg, R.A., Adams, M.W. and Arp, A.J. (2000) Life in extreme environments: Hydrothermal vents. Proc. Natl. Acad. Sci. USA 97, 12961-12962.

[41] Kaim, W. and Rall, J. (1996) Copper - a 'modern' bioelement. Angew. Chem. Int. Ed. Engl. 35, 43-60.

[42] Odermatt, A., Krapf, R. and Solioz, M. (1994) Induction of the putative copper ATPases, CopA and CopB, of Enterococcus hirae by $\mathrm{Ag}^{+}$and $\mathrm{Cu}^{2+}$, and $\mathrm{Ag}^{+}$extrusion by CopB. Biochem. Biophys. Res. Commun. 202, 4448. 
[43] Wunderli-Ye, H. and Solioz, M. (2001) Purification and functional analysis of the copper ATPase CopA of Enterococcus hirae. Biochem. Biophys. Res. Commun. 280, 713-719.

[44] Fan, B., Grass, G., Rensing, C. and Rosen, B.P. (2001) Escherichia coli CopA N-terminal Cys $(\mathrm{X})_{2}$ Cys motifs are not required for copper resistance or transport. Biochem. Biophys. Res. Commun. 286, 414 418.

[45] Solioz, M. and Odermatt, A. (1995) Copper and silver transport by CopB-ATPase in membrane vesicles of Enterococcus hirae. J. Biol. Chem. 270, 9217-9221.

[46] Voskoboinik, I., Greenough, M., La Fontaine, S., Mercer, J.F. and Camakaris, J. (2001) Functional studies on the Wilson copper P-Type ATPase and toxic milk mouse mutant. Biochem. Biophys. Res. Commun. 281, 966-970.

[47] Voskoboinik, I., Brooks, H., Smith, S., Shen, P. and Camakaris, J. (1998) ATP-dependent copper transport by the Menkes protein in membrane vesicles isolated from cultured Chinese hamster ovary cells. FEBS Lett. 435, 178-182.

[48] Francis, M.S. and Thomas, C.J. (1997) Mutants in the CtpA copper transporting P-type ATPase reduce virulence of Listeria monocytogenes. Microb. Pathog. 22, 67-78.

[49] Francis, M.S. and Thomas, C.J. (1997) The Listeria monocytogenes gene $\operatorname{ctp} \mathrm{A}$ encodes a putative P-type ATPase involved in copper transport. Mol. Gen. Genet. 253, 484-491.

[50] Lowe, A.M., Beattie, D.T. and Deresiewicz, R.L. (1998) Identification of novel staphylococcal virulence genes by in vivo expression technology. Mol. Microbiol. 27, 967-976.

[51] Mellano, M.A. and Cooksey, D.A. (1988) Nucleotide sequence and organization of copper resistance genes from Pseudomonas syringae pv. tomato. J. Bacteriol. 170, 2879-2883.

[52] Cooksey, D.A. (1994) Molecular mechanisms of copper resistance and accumulation in bacteria. FEMS Microbiol. Rev. 14, 381386.

[53] Wyler-Duda, P. and Solioz, M. (1996) Phosphoenzyme formation by purified, reconstituted copper ATPase of Enterococcus hirae. FEBS Lett. 399, 143-146.

[54] Bissig, K.-D., Wunderli-Ye, H., Duda, P. and Solioz, M. (2001) Structure-function analysis of purified Enterococcus hirae CopB copper ATPase: Effect of Menkes/Wilson disease mutation homologues. Biochem. J. 357, 217-223.

[55] Baerlocher, K. and Solioz, M. (2002) Disorders of copper, zinc and iron metabolism. In: A Physician's Guide to the Laboratory - Diagnosis of Inherited Metabolic Disease (Blau, N., Duran, M. and Blaskovics, M.E., Eds.), in press.

[56] Lee, Y.A., Hendson, M., Panopoulos, N.J. and Schroth, M.N. (1994) Molecular cloning, chromosomal mapping, and sequence analysis of copper resistance genes from Xanthomonas campestris pv Juglandis homology with small blue copper proteins and multicopper oxidase. J. Bacteriol. 176, 173-188.

[57] Mills, S.D., Lim, C.-K. and Cooksey, D.A. (1994) Purification and characterization of CopR, a transcriptional activator protein that binds to a conserved domain ( $c o p$ box) in copper-inducible promoters of Pseudomonas syringae. Mol. Gen. Genet. 244, 341-351.

[58] Brown, N.L., Barrett, S.R., Camakaris, J., Lee, B.T.O. and Rouch, D.A. (1995) Molecular genetics and transport analysis of the copperresistance determinant ( $p c o$ ) from Escherichia coli plasmid pRJ1004. Mol. Microbiol. 17, 1153-1166.

[59] Outten, F.W., Outten, C.E., Hale, J. and O'Halloran, T.V. (2000) Transcriptional activation of an Escherichia coli copper efflux regulon by the chromosomal MerR homologue, CueR. J. Biol. Chem. 275, 31024-31029.

[60] Stoyanov, J.V., Hobman, J.L. and Brown, N.L. (2001) CueR (YbbI) of Escherichia coli is a MerR family regulator controlling expression of the copper exporter CopA. Mol. Microbiol. 39, 502-512.

[61] Odermatt, A. and Solioz, M. (1995) Two trans-acting metalloregulatory proteins controlling expression of the copper-ATPases of Enterococcus hirae. J. Biol. Chem. 270, 4349-4354.
[62] Odermatt, A., Suter, H., Krapf, R. and Solioz, M. (1993) Primary structure of two P-type ATPases involved in copper homeostasis in Enterococcus hirae. J. Biol. Chem. 268, 12775-12779.

[63] Himeno, T., Imanaka, T. and Aiba, S. (1986) Nucleotide sequence of the penicillinase repressor gene penI of Bacillus licheniformis and regulation of penP and penI by the repressor. J. Bacteriol. 168, $1128-1132$.

[64] Suzuki, E., Kuwahara Arai, K., Richardson, J.F. and Hiramatsu, K. (1993) Distribution of mec regulator genes in methicillin-resistant Staphylococcus clinical strains. Antimicrob. Agents Chemother. 37, 1219-1226.

[65] Rowland, S.J. and Dyke, K.G. (1990) Tn552, a novel transposable element from Staphylococcus aureus. Mol. Microbiol. 4, 961-975.

[66] Wittman, V. and Wong, H.C. (1988) Regulation of the penicillinase genes of Bacillus licheniformis: interaction of the pen repressor with its operators. J. Bacteriol. 170, 3206-3212.

[67] Anderson, J.E., Ptashne, M. and Harrison, S.C. (1987) Structure of the repressor-operator complex of bacteriophage 434. Nature 326, 846-852.

[68] Zhou, P.B. and Thiele, D.J. (1991) Isolation of a metal-activated transcription factor gene from Candida glabrata by complementation in Saccharomyces cerevisiae. Proc. Natl. Acad. Sci. USA 88, 61126116.

[69] Dobi, A., Dameron, C.T., Hu, S., Hamer, D. and Winge, D.R. (1995) Distinct regions of $\mathrm{Cu}(\mathrm{I}) \bullet \mathrm{ACE} 1$ contact two spatially resolved DNA major groove sites. J. Biol. Chem. 270, 10171-10178.

[70] Heredia, J., Crooks, M. and Zhu, Z. (2001) Phosphorylation and $\mathrm{Cu}^{+}$coordination-dependent DNA binding of the transcription factor Maclp in the regulation of copper transport. J. Biol. Chem. 276, 8793-8797.

[71] Narula, S.S., Winge, D.R. and Armitage, I.M. (1993) Copper-substituted and silver-substituted yeast metallothioneins - sequential $\mathrm{H}^{1}$ NMR assignments reflecting conformational heterogeneity at the C-terminus. Biochemistry 32, 6773-6787.

[72] Strausak, D. and Solioz, M. (1997) CopY is a copper-inducible repressor of the Enterococcus hirae copper ATPases. J. Biol. Chem. 272, 8932-8936.

[73] Wunderli-Ye, H. and Solioz, M. (1999) Effects of promoter mutations on the in vivo regulation of the cop operon of Enterococcus hirae by copper(I) and copper(II). Biochem. Biophys. Res. Commun. 259, 443-449.

[74] Cobine, P., Wickramasinghe, W.A., Harrison, M.D., Weber, T., Solioz, M. and Dameron, C.T. (1999) The Enterococcus hirae copper chaperone CopZ delivers copper(I) to the CopY repressor. FEBS Lett. 445, 27-30.

[75] Cobine, P., Jones, C.E., Wickramasinghe, W.A., Solioz, M. and Dameron, C.T. (2002) Interaction of copper binding proteins from Enterococcus hirae. In: Handbook of Copper Pharmacology and Toxicology (Massaro, E.J., Ed.), pp. 177-186. Humana Press, Totowa, NJ.

[76] Cobine, P.A., George, G.N., Jones, C.E., Wickramasinghe, W.A., Solioz, M. and Dameron, C.T. (2002) Copper transfer from the $\mathrm{Cu}(\mathrm{I})$ chaperone, $\mathrm{CopZ}$, to the repressor, $\mathrm{Zn}$ (II)CopY: Metal coordination environments and protein interactions. Biochemistry 41 , 5822-5829.

[77] Cobine, P.A., Jones, C.E. and Dameron, C.T. (2002) Role for zinc(II) in the copper(I) regulated protein CopY. J. Inorg. Biochem. 88, 192196.

[78] Endo, G. and Silver, S. (1995) CadC, the transcriptional regulatory protein of the cadmium resistance system of Staphylococcus aureus plasmid pI258. J. Bacteriol. 177, 4437-4441.

[79] O'Halloran, T.V. and Culotta, V.C. (2000) Metallochaperones, an intracellular shuttle service for metal ions. J. Biol. Chem. 275, 25057-25060.

[80] Lamb, A.L., Torres, A.S., O'Halloran, T.V. and Rosenzweig, A.C. (2000) Heterodimer formation between superoxide dismutase and its copper chaperone. Biochemistry 39, 14720-14727. 
[81] Huffman, D.L. and O'Halloran, T.V. (2001) Function, structure, and mechanism of intracellular copper trafficking proteins. Annu. Rev. Biochem. 70, 677-701.

[82] Harrison, M.D., Jones, C.E., Solioz, M. and Dameron, C.T. (2000) Intracellular copper routing: The role of copper chaperones. Trends Biochem. Sci. 25, 29-32.

[83] Rosenzweig, A.C. (2001) Copper delivery by metallochaperone proteins. Acc. Chem. Res. 34, 119-128.

[84] Wimmer, R., Herrmann, T., Solioz, M. and Wüthrich, K. (1999) NMR structure and metal interactions of the CopZ copper chaperone. J. Biol. Chem. 274, 22597-22603.

[85] Wimmer, R., Dameron, C.T. and Solioz, M. (2002) Molecular hardware of copper homeostasis in Enterococcus hirae. In: Handbook of Copper Pharmacology and Toxicology (Massaro, E.J., Ed.), pp. 527542. Humana Press, Totowa, NJ.

[86] Multhaup, G., Strausak, D., Bissig, K.-D. and Solioz, M. (2001) Interaction of the CopZ copper chaperone with the CopA copper ATPase of Enterococcus hirae assessed by surface plasmon resonance. Biochem. Biophys. Res. Commun. 288, 172-177.

[87] Arnesano, F., Banci, L., Bertini, I., Cantini, F., Ciofi-Baffoni, S., Huffman, D.L. and O'Halloran, T.V. (2001) Characterization of the binding interface between the copper chaperone Atx1 and the first cytosolic domain of Ccc2 ATPase. J. Biol. Chem. 276, 41365 41376 .

[88] Brown, N.L., Camakaris, J., Lee, B.T., Williams, T., Morby, A.P., Parkhill, J. and Rouch, D.A. (1991) Bacterial resistances to mercury and copper. J. Cell Biochem. 46, 106-114.

[89] Pufahl, R.A., Singer, C.P., Peariso, K.L., Lin, S., Schmidt, P.J., Fahrni, C.J., Culotta, V.C., Penner-Hahn, J.E. and O'Halloran, T.V. (1997) Metal ion chaperone function of the soluble $\mathrm{Cu}(\mathrm{I})$ receptor Atx1. Science 278, 853-856.

[90] Lu, Z.H. and Solioz, M. (2001) Copper-induced proteolysis of the CopZ copper chaperone of Enterococcus hirae. J. Biol. Chem. 276, $47822-47827$.

[91] Lu, Z.H., Dameron, C.T. and Solioz, M. (2003) The Enterococcus hirae paradigm of copper homeostasis: Copper chaperone turnover, interactions, and transactions. Biometals 16, 137-143.
[92] Solioz, M. (2002) Role of proteolysis in copper homeostasis. Biochem. Soc. Trans. 30, 688-691.

[93] Gottesman, S. and Maurizi, M.R. (1992) Regulation by proteolysis: energy-dependent proteases and their targets. Microbiol. Rev. 56, 592-621.

[94] Gottesman, S. (1996) Proteases and their targets in Escherichia coli. Annu. Rev. Genet. 30, 465-506.

[95] Ooi, C.E., Rabinovich, E., Dancis, A., Bonifacino, J.S. and Klausner, R.D. (1996) Copper-dependent degradation of the Saccharomyces cerevisiae plasma membrane copper transporter $\mathrm{Ctrlp}$ in the apparent absence of endocytosis. EMBO J. 15, 3515-3523.

[96] Zhu, Z., Labbe, S., Pena, M.M. and Thiele, D.J. (1998) Copper differentially regulates the activity and degradation of yeast Mac1 transcription factor. J. Biol. Chem. 273, 1277-1280.

[97] Li, H.H. and Merchant, S. (1995) Degradation of plastocyanin in copper-deficient Chlamydomonas reinhardtii. Evidence for a protease-susceptible conformation of the apoprotein and regulated proteolysis. J. Biol. Chem. 270, 23504-23510.

[98] Rapisarda, V.A., Montelongo, L.R., Farias, R.N. and Massa, E.M. (1999) Characterization of an NADH-linked cupric reductase activity from the Escherichia coli respiratory chain. Arch. Biochem. Biophys. 370, 143-150.

[99] Rapisarda, V.A., Chehin, R.N., De Las, R.J., Rodriguez-Montelongo, L., Farias, R.N. and Massa, E.M. (2002) Evidence for $\mathrm{Cu}(\mathrm{I})$ thiolate ligation and prediction of a putative copper-binding site in the Escherichia coli NADH dehydrogenase-2. Arch. Biochem. Biophys. 405, 87-94.

[100] Wunderli-Ye, H. and Solioz, M. (1998) Regulation of the cop operon of Enterococcus hirae by the CopY repressor and copper. In: Metal Ions in Biology and Medicine (Collery, P., Brätter, P., Negretti de Brätter, V., Khassanova, L. and Etienne, J.-C., Eds.), pp. 109-113. John Libbey Eurotext, Paris.

[101] Hassett, R. and Kosman, D.J. (1995) Evidence for Cu(II) reduction as a component of copper uptake by Saccharomyces cerevisiae. J. Biol. Chem. 270, 128-134.

[102] Rawlings, D.E. (2002) Heavy metal mining using microbes. Annu. Rev. Microbiol. 56, 65-91. 